Journal of Animal and Veterinary Advances 10 (5): 674-678, 2011

ISSN: $1680-5593$

(C) Medwell Journals, 2011

\title{
Spatio-Temporal Variations in Nutritive Quality and Mineral Contents of Diets by Grazing Steers in Native Range
}

\author{
${ }^{1}$ M. Murillo Ortiz, ${ }^{1}$ E. Herrera Torres, ${ }^{1} \mathrm{O}$. Reyes Estrada, \\ ${ }^{2}$ J.N. Gurrola Reyes and ${ }^{3}$ F.G. Rios Rincon \\ ${ }^{1}$ Facultad de Medicina Veterinaria y Zootecnia, \\ Universidad Juarez del Estado de Durango, 34000 Durango, Dgo, Mexico \\ ${ }^{2}$ CIIDIR-IPN, Unidad Durango, Mexico \\ ${ }^{3}$ Facultad de Medicina Veterinaria y Zootecnia, \\ Universidad Autonoma de Sinaloa, Mexico
}

\begin{abstract}
The objective of this study was to determine and compare seasonally the nutritive quality and mineral contents of diets by grazing steers during 2 consecutive years. For the statistical analysis a repeated measure design was used. There was not year x season interaction for Organic Matter (OM), Crude Protein (CP), Neutral Detergent Fiber (NDF), In vitro DM Digestibility (IVDMD) and Metabolizable Energy (ME) ( $>0.05)$. Researchers found differences in CP content, IVDMD and ME between years $(\mathrm{p}<0.05)$. The higher values in these variables were registered in 2004. CP content was $20 \%$ higher in 2004 . However, NDF content was $8 \%$ higher in 2005 that in 2004. There was not year $x$ season interaction for the minerals evaluated $(p>0.05)$. Nevertheless, the values of Calcium (Ca), Phosphorus (P), Sodium (Na), Potassium (K), Magnesium (Mg), Zinc $(\mathrm{Zn})$, Selenium $(\mathrm{Se})$, Manganese $(\mathrm{Mn})$ and Copper $(\mathrm{Cu})$ were different between years $(\mathrm{p}<0.05)$ and seasons $(p<0.01)$. With the exception of $P$, the diet consumed for cattle throughout of the years and seasons had appropriate amounts of $\mathrm{Ca}, \mathrm{Na}, \mathrm{K}, \mathrm{Mg}, \mathrm{Zn}, \mathrm{Se}, \mathrm{Mn}$ and $\mathrm{Co}$ to meet requirements of beef cattle grazing native rangelands. The information generated in this study can be used for the formulation of protein, energy and mineral supplements according to the season of year.
\end{abstract}

Key words: Steers, grazing, nutritive quality, minerals, diets, rangelands

\section{INTRODUCTION}

Some studies report that as a result of drastic climate change, the animals in the region of north of Mexico have periods of 90-100 days of favorable grazing conditions and if the number of days is reduced, the survival of these animals may be in jeopardy. Under long-term drought conditions, the evaluation of nutritive quality of the diet selected by grazing cattle across seasons is essential to establishing strategic programs of dietary supplementation (Klopfenstein et al., 2001). However, the grazing beef cattle also require a number of mineral for optimal growth and reproduction. According to $\mathrm{McD}$ owell (1992) the most critical mineral for grazing cattle are: Ca, P, $\mathrm{Na}, \mathrm{Co}, \mathrm{Cu}, \mathrm{Se}$ and $\mathrm{Zn}$. During disease states mineral requirements of cattle may be affected by immune system response. High concentrations of Zinc have been shown to be beneficial to the ruminant's health during disease and $\mathrm{Zn}, \mathrm{Cu}, \mathrm{Se}$ and Iron $(\mathrm{Fe})$ seem to be necessary for inmunocompetence (NRC, 2000). The knowledge of mineral content of diet selected by grazing cattle is necessary to design supplementation strategies under range conditions. During the dry season the inadequate intake of forage by grazing cattle that result from the low protein and high fiber content, may decrease the total mineral intake while in the wet season, high forage availability with higher concentration of protein and energy may improve growth of cattle but mineral requirements are increased and deficiencies may be more drastic if cattle are not supplemented (McDowell, 1985). The objective of this study was to determine and compare, seasonally, across two consecutive years the nutritive quality and mineral contents of diets by grazing steers.

\section{MATERIALS AND METHODS}

Study area: The study was carried during 2 consecutive years (2004 and 2005) in a medium-sized shrub-grassland east of the city of Durango, Mexico $\left(24^{\circ} 22 \mathrm{~N}, 104^{\circ} 32^{\prime} \mathrm{W}\right.$

Corresponding Author: M. Murillo Ortiz, Facultad de Medicina Veterinaria y Zootecnia, Universidad Juarez del Estado de Durango, 34000 Durango, Dgo, Mexico 
at an altitude of about $1938 \mathrm{~m}$ above sea level) which has a dry temperate $\left(\mathrm{BS}_{1} \mathrm{k}\right)$ climate with average annual temperature and rainfall of $17.5^{\circ} \mathrm{C}$ and $450 \mathrm{~mm}$, respectively. Rainfall in 2004 was above average at $547.5 \mathrm{~mm}$ and 2005 was drier that normal at $238.0 \mathrm{~mm}$. The study area covers 2,000 ha $(6 \mathrm{ha} / \mathrm{AU})$ with an average of forage biomass of $1,796 \mathrm{~kg}$ of DM/ha. During the 2 years of the study, we estimated vegetation cover using minimum area sampling with nested points (Franco et al., 1985). Dominant grass species included Melinis repens Willd (rose natal grass), Chloris virgata (feather fingergrass), Bouteloua gracilis (blue grama), Aristida adscensionis ( 6 weeks threeawn) and Andropogon barbinodis (cane bluestem); bushes: Acacia tortuosa (poponax), Prosopis juliflora (mezquite), Opuntia sp. (prickly pears and chollas), Mimosa biuncifera (mimosa); plus a wide variety of annual herbs.

Animals and collection of diet samples: We used four steers fistulated in the esophagus with a live weight of $350 \pm 3 \mathrm{~kg}$. Surgery was performed on the steers according to procedures approved by the University of Durango Laboratory Care Advisory Committee. We collected diet samples with the steers fistulated of esophagus during four consecutive days at $07: 00 \mathrm{~h}$ for $45 \mathrm{~min}$ periods (Karn, 2000), 8 times annually: Jan 2-5, Feb 4-7, Apr 13-16, May 15-18, Jul 20-23, Aug 11-14, Oct 12-15 and Nov 20-23. The first two collection periods were considered to be in winter; 3 and 4, spring; 5 and 6, summer and 7 and 8, fall. Collection periods were conducted at these times to reflect phenological changes in the rangelands.

Nutritive quality: Esophageal samples were dried at $60^{\circ} \mathrm{C}$ for $48 \mathrm{~h}$ and ground through a $2 \mathrm{~mm}$ screen in a Wiley mill and were determined Dry Matter (DM), CP, OM (AOAC, 1999), NDF (Van Soest et al., 1991) and IVDMD (Daisy II ANKOM Technology, Macedon NY USA). We estimated $\mathrm{ME}$ content with the formulas used by Waterman et al. (2007): Digestible Energy (DE; $\left.\mathrm{Mcal} \mathrm{kg}^{-1}\right)=[0.039 \times(\mathrm{OMD}$ g\%)]-0.10; $\mathrm{ME}\left(\mathrm{Mcal}(\mathrm{kg})=\mathrm{DE}\left(\mathrm{Mcal} \mathrm{kg}^{-1}\right) \times 0.82\right.$. Where $\mathrm{OMD}$ is the organic matter degradability obtained after $48 \mathrm{~h}$ incubation in the rumen. The Mcal of ME obtained was transformed to Mega Joule (MJ) from of 4.184 constant.

Minerals contents: Esophageal samples were incinerated in a muffle oven a $600^{\circ} \mathrm{C}$ during $5 \mathrm{~h}$. The ashes obtained were digested in a solution $\mathrm{HCl}-\mathrm{HNO}_{3}$ (Cherney, 2000). Concentrations of $\mathrm{Ca}, \mathrm{Mg}, \mathrm{K}, \mathrm{Na}, \mathrm{Cu} \mathrm{Mn}, \mathrm{Z}$ and Se were determined by atomic absorption spectrophotometry while $\mathrm{P}$ content was determined by a colorimetric procedure (Fink et al., 1979).
Statistical analysis: Data over month were analyzed as a repeated measure (split-split plot) design using the MIXED procedure by SAS (2003). The model included fixed effects for years, season and years $\mathrm{x}$ season interaction. The repeated effects was month and steers within years $\times$ season was used as the error term for the split-split plot. Autoregressive Order 1 was used as the covariance structure because it was better fitting structure based on comparison of covariance structures with Akaike and Bayesian information criterions (Littell et al., 1998). The comparison of means between years and season was performed using the LSMEANS (least squares means) statement of MIXED procedure.

\section{RESULTS AND DISCUSSION}

Nutritive quality: There was not year $\times$ season interaction for OM, PC, NDF, IVDDM and ME ( $>>0.05$; Table 1). Neither, we find significant differences in $O M$ content in the diet within years and seasons of this study $(\mathrm{p}>0.05)$ but we found differences in CP content, IVDDM and ME between years $(p<0.05)$. The higher values for these variables were registered in 2004 . However, NDF content was $8 \%$ higher in 2005 that in 2004 while CP content was $20 \%$ higher in 2004. These differences may be result of registered rainfall during the experimental period (Cline et al., 2009). CP, IVDDM and ME content were higher in summer and fall $(\mathrm{p}<0.05)$. Grings et al. (2004) and Olson et al. (2002) reported similar results across seasons. Also, Chavez and Gonzalez, mention that nutritive quality of the diet of grazing cattle in northern Mexico is higher in summer and fall versus winter and spring they attribute these differences to the phenology of rangelands. Consequently, these variables were also higher in the months of summer (July and August) and fall (October and November) that in the months of spring (April and May) and winter (January and February) $(\mathrm{p}<0.05)$.

Table 1: Least squares means for nutritive quality in the diet of grazing

\begin{tabular}{|c|c|c|c|c|c|}
\hline \multirow[b]{2}{*}{$\underline{\text { Parameters }}$} & $\mathrm{OM}$ & $\mathrm{CP}$ & $\mathrm{NDF}$ & IVDMD & \multirow{2}{*}{$\begin{array}{c}\mathrm{ME} \\
\left(\mathrm{MJ} \mathrm{kg}^{-1}\right)\end{array}$} \\
\hline & \multicolumn{4}{|c|}{ - } & \\
\hline \multicolumn{6}{|l|}{ Years (Y) } \\
\hline 2004 & 88.2 & $11.70^{\mathrm{a}}$ & $69.9^{b}$ & $64.20^{\mathrm{a}}$ & $11.70^{\mathrm{a}}$ \\
\hline 2005 & 87.2 & $9.60^{b}$ & $75.6^{\mathrm{a}}$ & $60.10^{b}$ & $5.40^{b}$ \\
\hline SEM & 2.2 & 2.10 & 1.1 & 1.30 & 1.60 \\
\hline \multicolumn{6}{|l|}{ Season (S) } \\
\hline Spring & 87.9 & $6.20^{\mathrm{b}}$ & $74.0^{b}$ & $57.10^{\mathrm{b}}$ & $8.70^{b}$ \\
\hline Summer & 88.3 & $11.90^{\mathrm{a}}$ & $67.5^{\mathrm{a}}$ & $65.50^{\mathrm{a}}$ & $10.00^{\mathrm{a}}$ \\
\hline Fall & 88.8 & $11.20^{\mathrm{a}}$ & $68.5^{\mathrm{a}}$ & $64.20^{\mathrm{a}}$ & $10.00^{\mathrm{a}}$ \\
\hline Winter & 89.0 & $5.90^{b}$ & $73.7^{\mathrm{b}}$ & $57.30^{b}$ & $8.30^{b}$ \\
\hline SEM & 1.2 & 0.99 & 1.1 & 0.98 & 0.87 \\
\hline Effects & $\mathrm{p}<$ & $\mathrm{p}<$ & $\mathrm{p}<$ & $\mathrm{p}<$ & $\mathrm{p}<$ \\
\hline $\mathrm{Y}$ & NS & $*$ & $*$ & $*$ & $*$ \\
\hline $\mathrm{S}$ & NS & $*$ & $*$ & $*$ & $*$ \\
\hline$\underline{\mathrm{Y} \times \mathrm{S}}$ & NS & NS & NS & NS & NS \\
\hline
\end{tabular}

${ }^{a b}$ Means with different superscripts, within column are significantly different $(p<0.05)$; SEM: Standard Error of Mean. $n=4$; NS: Not Significant $(p>0.05) ; *(p<0.05)$ 
Table 2: Least squares means for mineral content in the diet of grazing steers

\begin{tabular}{|c|c|c|c|c|c|c|c|c|c|}
\hline \multirow[b]{2}{*}{ Parameters } & $\mathrm{Ca}$ & $\mathrm{P}$ & $\mathrm{Mg}$ & $\mathrm{K}$ & $\mathrm{Na}$ & $\mathrm{Zn}$ & $\mathrm{Se}$ & $\mathrm{Mn}$ & $\mathrm{Cu}$ \\
\hline & \multicolumn{5}{|c|}{ - } & \multicolumn{4}{|c|}{ 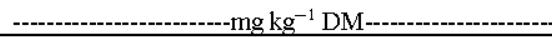 } \\
\hline \multicolumn{10}{|l|}{ Years $(\mathrm{Y})$} \\
\hline 2004 & $5.80^{\mathrm{a}}$ & $1.60^{\mathrm{a}}$ & $3.30^{\mathrm{a}}$ & $14.60^{\mathrm{a}}$ & $1.500^{\mathrm{a}}$ & $35.7^{\mathrm{a}}$ & $0.93^{\mathrm{a}}$ & $44.30^{\mathrm{a}}$ & $14.00^{\mathrm{a}}$ \\
\hline 2005 & 4. $70^{b}$ & $1.20^{b}$ & $2.60^{b}$ & $9.20^{b}$ & $1.300^{b}$ & $32.2^{b}$ & $0.82^{b}$ & $41.50^{b}$ & $12.00^{\circ}$ \\
\hline SEM & 0.22 & 0.16 & 0.80 & 1.10 & 0.920 & 1.20 & 0.09 & 1.40 & 1.60 \\
\hline \multicolumn{10}{|l|}{ Season (S) } \\
\hline Spring & $4.30^{b}$ & $1.20^{c}$ & $2.40^{\circ}$ & $8.40^{\mathrm{d}}$ & $1.100^{c}$ & $31.2^{c}$ & $0.64^{c}$ & $41.00^{c}$ & $11.00^{b}$ \\
\hline Summer & $6.20^{\mathrm{a}}$ & $1.80^{\mathrm{a}}$ & $3.80^{\mathrm{a}}$ & $16.80^{\mathrm{a}}$ & $1.900^{\mathrm{a}}$ & $38.4^{\mathrm{a}}$ & $1.00^{\mathrm{a}}$ & $47.00^{\mathrm{a}}$ & $15.00^{\mathrm{a}}$ \\
\hline Fall & $5.50^{\mathrm{a}}$ & $1.60^{\mathrm{ab}}$ & $3.50^{\mathrm{a}}$ & $11.00^{b}$ & $1.600^{b}$ & $34.5^{b}$ & $0.95^{\mathrm{a}}$ & $45.00^{b}$ & $14.00^{\mathrm{a}}$ \\
\hline Winter & $4.50^{b}$ & $1.40^{b c}$ & $2.50^{b}$ & $8.80^{c}$ & $1.200^{\circ}$ & $31.4^{c}$ & $0.83^{b}$ & $42.00^{c}$ & $12.00^{\circ}$ \\
\hline SEM & 0.70 & 0.52 & 0.41 & 0.16 & 0.100 & 0.84 & 0.10 & 0.13 & 0.17 \\
\hline Effects & $\mathrm{p}<$ & $\mathrm{p}<$ & $\mathrm{p}<$ & $\mathrm{p}<$ & $\mathrm{p}<$ & $\mathrm{p}<$ & $\mathrm{p}<$ & $\mathrm{p}<$ & $\mathrm{p}<$ \\
\hline $\mathrm{Y}$ & $*$ & $*$ & $*$ & $*$ & $*$ & $*$ & $*$ & $*$ & $*$ \\
\hline$S$ & *** & $* *$ & *** & *** & *** & *** & *** & $* *$ & *** \\
\hline$\underline{\mathrm{Y} \times \mathrm{S}}$ & NS & NS & NS & NS & NS & NS & NS & NS & NS \\
\hline
\end{tabular}

${ }_{\text {a-d }}$ Means with different superscripts, within column are significantly different $(p<0.05)$. SEM: Standard Error of Mean. $n=4$; NS: Not Significant ( $p>0.05$ ); $*(\mathrm{p}<0.05) ; * *(\mathrm{p}<0.01)$

Mineral content: There was not year $\times$ season interaction for the mineral evaluated ( $\mathrm{p}>0.05$; Table 2 ). However, the values of $\mathrm{Ca}, \mathrm{P} . \mathrm{Na}, \mathrm{K}, \mathrm{Mg}, \mathrm{Zn}$, Se $\mathrm{Mn}$ and $\mathrm{Cu}$ were greater in 2004 versus $2005(\mathrm{p}<0.05)$. The Ca content of diet selected was higher in summer and fall $(\mathrm{p}<0.01)$. In this study, the diet consumed for cattle throughout of the seasons had appropriate amounts of $\mathrm{Ca}$ to meet requirements of growing beef cattle $\left(4.0 \mathrm{~g} \mathrm{~kg}^{-1} \mathrm{DM}\right)$, beef gestating cows (1.6 $\left.\mathrm{g} \mathrm{kg}^{-1} \mathrm{DM}\right)$ and early lactation (2.8 $\left.\mathrm{g} \mathrm{kg}^{-1} \mathrm{DM}\right)(\mathrm{NRC}, 2000)$. Due to its low mobility, Ca concentration is lower in mature forage (Minson, 1990). This probably results from $\mathrm{Mg}$ availability being linked to soil $\mathrm{Ca}$ and $\mathrm{pH}$; increased $\mathrm{Ca}$ in acid soils favors $\mathrm{Mg}$ uptake by roots. Low $\mathrm{Al}, \mathrm{Mn}$ and $\mathrm{Fe}$ contents in acidic $\mathrm{pH}$ increases $\mathrm{Cu}$ and $\mathrm{Zn}$ uptake without affecting plant $\mathrm{Ca}$ concentration (Pope, 1971). The P concentration in the diet consumed for cattle was higher in 2004 versus 2005 $(p<0.05)$ as well as was greater in summer as compared to winter and spring $(p<0.01)$. However, in this research the $\mathrm{P}$ concentration was not sufficient for to meet requirements of beef cattle $\left(2.2,1.7\right.$ and $2.2 \mathrm{~g}$ of $\mathrm{P} \mathrm{kg}^{-1}$ of DM for growing beef cattle, beef pregnant cows and beef cows early lactation, respectively) (NRC, 2000). Greene, (2000) reported that due to slow growth and increased temperature, $\mathrm{P}$ decreases from $1.8-1.2 \mathrm{~g} \mathrm{~kg}^{-1} \mathrm{DM}$ during the dry season. The $\mathrm{Mg}$ content of diet selected was higher in summer and fall versus winter and spring ( $<<0.01)$. The $\mathrm{Mg}$ present in the diet consumed for cattle during seasons was sufficient to meet requirements of beef cattle $\left(1,1.2\right.$ and $2 \mathrm{~g}$ of $\mathrm{mg} \mathrm{kg}^{-1}$ of DM for growing beef cattle, beef gestating cows and beef cows early lactation, respectively) (NRC, 2000). The $\mathrm{K}$ content was affected by season of the year $(\mathrm{p}<0.01)$. Diet $\mathrm{K}$ content in all seasons was similar to required levels $\left(6,6\right.$ and $7 \mathrm{~g} \mathrm{~kg}^{-1}$ of DM for growing beef cattle, beef gestating cows and early lactation, respectively) (NRC, 2000). Grazing cattle normally receive sufficient $\mathrm{K}$ because forage contains high $\mathrm{K}$ levels (McDowell and Valle, 2000). The Na content of diet selected for cattle was different between seasons and years $(\mathrm{p}<0.01)$. The changes in $\mathrm{Na}$ content may be caused by atmospheric $\mathrm{Na}$ and geochemical factors (Minson, 1990). In this research, the $\mathrm{Na}$ content was sufficient for to meet requirements of beef cattle $\left(0.6,0.6\right.$ and $1 \mathrm{~g}$ of $\mathrm{Na} \mathrm{kg}^{-1}$ of DM for growing beef cattle, beef cows gestating and early lactation, respectively) (NRC, 2000).

The $\mathrm{Zn}$ content was higher in summer and lower in spring $(\mathrm{p}<0.01)$. The diet consumed for cattle throughout of the seasons and years had appropriate amounts of $\mathrm{Zn}$ to meet requirements of beef cattle $(30,30$ and $30 \mathrm{mg}$ of $\mathrm{Zn} \mathrm{kg} \mathrm{k}^{-1}$ of DM for growing beef cattle, beef gestating cows and early lactation, respectively) (NRC, 2000). Similarly, Moya et al. (2002) reported variations seasonal in $\mathrm{Zn}$ content of eight species shrubs occur in North Mexico. The Se content was affected by season of the year $(p<0.01)$ with highest values in summer and lower in spring $(\mathrm{p}<0.01)$. This coincides with Jumba et al. (1996) who reported that rainfall influenced on forage Se content. In this study, Se content was higher that the minimal requirements recommended for cattle throughout of the seasons and years (growing beef cattle $10 \mathrm{mg} \mathrm{kg}^{-1} \mathrm{DM}$, beef cows gestating $10 \mathrm{mg} \mathrm{kg}^{-1}$ DM and early lactation $\left.10 \mathrm{mg} \mathrm{kg}^{-1} \mathrm{DM}\right)(\mathrm{NRC}, 2000)$. Likewise, the $\mathrm{Mn}$ content of diets was higher in summer and lower in spring $(p<0.01)$ and had adequate amounts to meet requirements of beef cattle $\left(20,40\right.$ and $40 \mathrm{mg}$ of $\mathrm{Mn} \mathrm{kg}^{-1}$ of DM for growing beef cattle, beef gestating cows and early lactation, respectively) (NRC, 2000). Nonetheless, McDowell (2003) has been reported in USA and other countries $\mathrm{Mn}$ scarcity for ruminants under grazing conditions. Similarly, the Cu content of diets was higher in summer and lower in spring $(p<0.01)$. During dry season might have also reduced availability of Cu (Spears, 1994). 
The diet consumed for cattle throughout of the seasons and years had adequate amounts of $\mathrm{Cu}$ to meet requirements of growing beef cattle ( $\left.10 \mathrm{mg} \mathrm{kg}^{-1} \mathrm{DM}\right)$, beef cows gestating (10 $\mathrm{mg} \mathrm{kg}^{-1} \mathrm{DM}$ ) and early lactation (10 $\mathrm{mg} \mathrm{kg}^{-1} \mathrm{DM}$ ) grazing native rangelands (NRC, 2000). Under conditions similar to those of the study, Mayland and Lesperance (1977), Kalmbacher et al. (1984) and Arthington and Swenson (2004) found differences between seasons in contents of Ca, P. Na, K, Mg, Zn, Mn and $\mathrm{Cu}$. According to McDowell (2003) and Haenlein and Ramirez (2007) these differences in the mineral contents of diets may be attributed to the interaction of a number factor including soil, plant species, yield, pasture management, climate (temperature and rainfall) and stages of maturity. The fiber content increases with the rangelands maturity (Murillo et al., 2006). A sizable amount on the total $\mathrm{Ca}, \mathrm{Cu}$ and $\mathrm{Zn}$ was associated with the Neutral Detergent Fiber (NDF) fraction (Van Soest, 1994). The association of certain minerals with fiber or other insoluble plant components could decrease the rate and extent of mineral release from forages in the ruminant gastrointestinal tract (Spears, 1994). In addition, all factors that determine the mineral contents of the vegetative parts of plants, basically influence the mineral intakes of range livestock grazing system (McDowell, 1996). Nonetheless, the mineral content of diet grazing cattle obtained from esophageal samples should be viewed with some caution because leaching by saliva might overestimate mineral concentrations mainly of $\mathrm{Na}, \mathrm{K}, \mathrm{Mn}$ and $\mathrm{Fe}$ (Hoehne et al., 1967).

\section{CONCLUSION}

The results indicate that drought induced by spring and winter results in decreased diet quality nutritive because to the decreased of CP and increase of NDF. The protein supplementation and energy might be beneficial for cattle grazing during spring and winter. Further, optimal type and level of protein and energy supplementation under spring drought condition have yet to be determined.

During wet season, the mineral content was higher compared to dry season. $\mathrm{Ca}, \mathrm{Mg}, \mathrm{Na}, \mathrm{Zn}, \mathrm{Se}, \mathrm{Mn}$ and $\mathrm{Cu}$ supplied by the diet, meet the requirements of grazing native rangelands cattle while $P$ content was deficient in both years and seasons. The study provides new knowledge can be used to make more precise the formulation of supplements that grazing cattle need to improve their health, immunity, lactation, growth and reproduction.

\section{ACKNOWLEDGEMENTS}

Researchers thank the CONACYT-State Government of Durango Mixed Fund (FOMIX-DGO; Project: DGO-2002-CO1-2522) for funding the investigation.

\section{REFERENCES}

AOAC, 1999. Official Methods of Analysis of the Association of Official Agricultural Chemists. 16th Edn., AOAC International, Gaithersburg, MD, USA.

Arthington, J.D. and C.K. Swenson, 2004. Effects of trace mineral source and feeding method on the productivity of grazing Braford cows. Prof. Anim. Sci., 20: 155-161.

Cherney, D.J.R., 2000. Characterization of Forages by Chemical Analysis. In: Forage Evaluation in Ruminant Nutrition, Givens, D.I., E. Owen, R.F.E. Axford and H.M. Omed (Eds.). CAB International, Wallingford, UK., pp: 275-300.

Cline, H.J., B.W. Neville, G.P. Lardy and J.S. Caton, 2009. Influence of advancing season on dietary composition, intake, site of digestion and microbial efficiency in beef steers grazing a native range in Western North Dakota. J. Anim. Sci., 87: 375-383.

Fink, K.R., L.R. McDowell, P.H. Miles, N.S. Wilkinson, J.D. Funk and J.H. Conrad, 1979. Methods of Mineral Analysis for Plant and Animal Tissues. 2nd Edn., University of Florida, Gainsville.

Franco, L.J., A.G. De-la-Cruz, G.A. Cruz, R.A. Rocha and S.N. Navarrete et al., 1985. Manual de Ecologia. Editorial Trillas, Mexico.

Greene, L.W., 2000. Designing mineral supplementation of forage programs for beef cattle. J. Anim. Sci., 77: 1-9.

Grings, E.E., M.R. Shorth, M.R. Haferkamp and R.K. Heitschmidt, 2004. Late summer protein supplementation for yearling cattle. J. Range. Manage., 57: 358-364.

Haenlein, G.J.W. and R.G. Ramirez, 2007. Potential mineral deficiencies on arid rangelands for small ruminants with special reference to Mexico. Small Rum. Res., 68: $35-41$.

Hoehne, O.E., D.C. Clanton and C.L. Streeter, 1967. Chemical changes in esophageal fistula samples caused by salivary contamination and preparation. J. Anim. Sci., 26: 628-631.

Jumba, I.O., N.F. Suttle, E.A. Hunter and S.O. Wandiga, 1996. Effects of Botanical Composition, Soil Organic and Composition on Mineral Concentrations in Dry Season Pastures in Weatern Kenya. In: Environment Geochemistry and Health, Appleton, J.D., R. Fuge and G.J.H. MarCall (Eds.). Geolical Society Special Publicaction, London, UK., pp: 39-45. 
Kalmbacher, R.S., K.R. Long and F.G. Martin, 1984. Seasonal mineral concentration in diets of esophageally fistulated steers on three range areas. J. Range. Manage., 37: 36-38.

Karn, J.F., 2000. Supplementation of yearling steers grazing northern Great Plains rangelands. J. Range Manage., 53: 170-175.

Klopfenstein, T.J., R.A. Mass, K.W. Creighten and H.H. Patterson, 2001. Estimating forage protein degradation in the rumen. J. Anim. Sci., 79: 217-217.

Littell, R.C., P.R. Henry and C.B. Ammerman, 1998. Statistical analysis of repeated measures data using SAS procedures. J. Anim. Sci., 76: 1216-1231.

Mayland, H.F. and A.L. Lesperance, 1977. Mineral composition of rumen fistula samples compared to diets. J. Range. Manage., 39: 338-390.

McDowell, L.R. and G. Valle, 2000. Major Minerals in Forages. In: Forage Evaluation in Ruminant Nutrition, Givens, D.I., E. Owens and H.M. Omed (Eds.). CABI Publishing, Oxon, UK., pp: 373-397.

McDowell, L.R., 1985. Nutrition of Grazing Ruminants in Warm Climates. Academic Press, New York.

McDowell, L.R., 1992. Mineral in Animal and Human. Academic Prees Inc., USA., pp: 387.

McDowell, L.R., 1996. Feeding mineral to cattle on pasture. Anim. Feed Tech., 60: 247-271.

McDowell, L.R., 2003. Mineral in Animal and Human. 2nd Edn., Elsevier, The Netherlands, pp: 256-315.

Minson, D.J., 1990. Forages in Ruminants Nutrition. Academic Press, California, USA.

Moya, R.J.G., R.G. Ramirez, R. Foroughbackhch, L.A. Hauad and R.H. Gonzalez, 2002. Variacion estacional de minerales en las hojas de ocho especies arbustivas. Ciencia UANL, 5: 59-65.
Murillo, O.M., O. Reyes, E. Herrera, M. Guerrero and G. Nevarez et al., 2006. Chemical composition, intake and in vitro gas production of forage selected by cattle in a grassland of Northern Mexico. J. Anim. Sci., 84: 23-23.

NRC, 2000. Nutrient Requirements of Domestic Animals, Nutrient Requirements of Beef Cattle. 7th Edn., NRC, Washington, DC, USA.

Olson, K.C., J.R. Jaeger, J.R. Brethour and T.B. Avery, 2002. Steer nutritional response to intensive-early stocking on short-grass rangeland. J. Range Manage., 55: 222-228.

Pope, A.L., 1971. A review of recent mineral research with sheep. J. Anim. Sci., 33: 1332-1338.

SAS, 2003. SAS User's Guide (Release 9.1). SAS Inst. Inc., Cary, $\mathrm{NC}$.

Spears, J.W., 1994. Minerals in Forages. In: Forage Quality, Evaluation and Utilization, Fahey, G.C., M. Collins and D.R. Mertens (Eds.). American Society of Agronomy, Madison, WI., pp: 281-317.

Van Soest, P.J., 1994. Nutritional Ecology of the Ruminant. 2nd Edn., Cornell University Press, Ithaca, New York, pp: 373.

Van Soest, P.J., J.B. Robertson and B.A. Lewis, 1991. Methods for dietary fiber, neutral detergent fiber and non-starch polisacharides in relation to animal nutrition. J. Dairy. Sci., 74: 3583-3597.

Waterman, R.C., E.E. Grings, T.W. Geary, A.J. Roberts, L.J. Alexander and M.D. MacNeil, 2007. Influence of seasonal forage quality on glucose kinetics of young beef cows. J. Anim. Sci., 85: 2582-2595. 